\title{
DEVELOPMENT OF CARBON TETRACHLORIDE-INDUCED CHRONIC HEPATOTOXICITY MODEL IN RATS AND ITS APPLICATION IN EVALUATION OF HEPATOPROTECTIVE ACTIVITY OF SILYMARIN
}

\author{
GOPI H SHAH ${ }^{1}$, BHARAT G PATEL ${ }^{2}$, GAURANG B SHAH ${ }^{3}$ \\ ${ }^{1}$ Department of Pharmacology and Toxicology, Ramanbhai Patel College of Pharmacy, Charotar University of Science and Technology, \\ CHARUSAT - Campus, Changa, Petlad, Anand - 388 421, Gujarat, India. ${ }^{2}$ Department of Pharmacology, Charotar University of Science \\ and Technology, CHARUSAT - Campus, Changa, Petlad, Anand - 388 421, Gujarat, India. ${ }^{3}$ Department of Pharmacology and Toxicology, \\ K.B.Institute of Pharmaceutical Education and Research, Sector-23, GH-6, Gandhinagar, Gujarat, India. Email: ghshah17213@gmail.com
}

Received: 25 March 2017, Revised and Accepted: 11 May 2015

Objective: The objective of the present work is to develop carbon tetrachloride $\left(\mathrm{CCl}_{4}\right)$-induced chronic hepatotoxicity model in rats and its application in evaluation of hepatoprotective activity of silymarin.

Methods: Animals were divided into four groups. Three groups were the disease induction group and $4^{\text {th }}$ was the treatment group. In disease induction groups, chronic liver injury was induced by administration of $\mathrm{CCl}_{4}$ through intraperitoneal route $(1 \mathrm{ml} / \mathrm{kg})$ for 7-8 weeks. For treatment Group, $1 \mathrm{ml}$ silymarin suspension (orally) and $\mathrm{CCl}_{4}$ was given for 7-8 weeks. During disease induction and treatment period (7-8 weeks), blood samples were collected and serum was separated which in turn used to analyze liver function tests such as serum glutamate oxaloacetate transaminase (SGOT), serum glutamate pyruvate transaminase (SGPT), alkaline phosphate (ALP), direct bilirubin, total protein (TP), and albumin (Alb) levels. Along with liver functional tests, tests to check cholesterol, glucose, and malondialdehyde (MDA) were also performed. Liver fibrosis and cirrhosis was quantified by histopathological studies of small portion of the excised liver. Model was validated by repetition of the experiment. Intermediate dissection was carried out to measure an extent of liver damage.

Result: Serum SGOT, SGPT, ALP, and direct bilirubin were found to be significantly higher in $\mathrm{CCl}_{4}$ intoxicated rats. TP and Alb were decreased, and MDA was found to be significantly higher in $\mathrm{CCl}_{4}$ intoxicated rats, which is the main end product of lipid peroxidation. Whereas in the treatment group silymarin improved the liver functions in $\mathrm{CCl}_{4}$ toxicated drug.

Conclusion: We conclude that protein oxidation may play a role in the pathogenesis of $\mathrm{CCl}_{4}$ induced liver injury. The accumulation of oxidized proteins may be an early indication of $\mathrm{CCl}_{4}$ induced liver damage and silymarin found to be effective in liver injury by inhibiting protein oxidation.

Keywords: Liver fibrosis, Free radicals, Lipid peroxidation, Oxidative stress, Carbon tetrachloride, Liver biomarkers.

(c) 2017 The Authors. Published by Innovare Academic Sciences Pvt Ltd. This is an open access article under the CC BY license (http://creativecommons. org/licenses/by/4. 0/) DOI: http://dx.doi.org/10.22159/ajpcr.2017.v10i8.18701

\section{INTRODUCTION}

The liver is the largest organ within the body, involved in metabolism of drugs. Among total liver mass, hepatocytes are involved in detoxification of a variety of drugs, vitamins, hormones, and environmental toxicants and the metabolism of amino acids and ammonia, biochemical oxidation reactions. Kupffer cells are a reservoir of fixed macrophages, which play a protective role against gut-derived toxins that have escaped into the portal circulation. Endotoxins are mainly responsible for the production of cytokines. Other specific liver cell types also perform the unique function. The liver is the main organ in the first line of defense; it appears to be the most common target organ damaged by industrial chemicals [1]. Occupational and environmental liver diseases may present with a wide clinical spectrum ranging from asymptomatic liver enzyme elevation to acute liver failure, cirrhosis, and cancer. Hepatocellular necrosis may occur due to most industrial chemicals, including solvents, exhibit dose-dependent hepatocyte cytotoxicity [2].

Liver injury of various etiologies can cause liver fibrosis, which further progresses to end stage liver failure (cirrhosis and ascites) which was characterized by progressive accumulation of connective tissue in the liver [3]. Recruitment of immune cells of the liver leads to the activation of local Kupffer cells, which can further promote the fibrotic process through secretion of inflammatory and fibrogenic cytokines. The causes of liver injuries are toxic chemicals such as antibiotics, chemotherapeutic agent's aflatoxins, chlorinated hydrocarbons, and carbon tetrachloride $\left(\mathrm{CCl}_{4}\right)$.

Due to multiplicity and complexity of liver function as no single test is enough to define the extent of liver damage and to evaluate hepatoprotective activity of the drugs. As every toxicant has unique mode of action, so selection of toxicant depends on type and nature of liver injury required, which produce the specific type of damage [4]. $\mathrm{CCl}_{4}$ proves highly useful as an experimental model for the study of certain hepatotoxic effects [5]. It consistently produces liver injury in many species. The formations of free radicals are responsible in pathogenesis of $\mathrm{CCl}_{4}$-induced liver injury in rats and alcohol-induced liver injury in humans. Free radicals are the main culprit for lipid peroxidation which leads to oxidative damage to cellular proteins and alters its functions. The main principle effect of $\mathrm{CCl}_{4}$-induced liver injury is the lipid peroxidative degradation of biomembrane [6]. In liver biotransformation of $\mathrm{CCl}_{4}$ produce its active metabolite trichloromethyl free radical $\left(\mathrm{CCl}_{3}^{*}\right)$ [7], which binds to the macromolecule and induces peroxidative degradation of membrane lipids leads to the formation of toxic aldehyde, which is responsible for the liver injury.

In the absence of consistent liver-protective drugs in modern medicine, a large number of plant-derived natural products such as flavonoids, terpenoids, and steroids have received considerable attention during 
recent years due to their diverse pharmacological properties, including antioxidant and hepatoprotective activity [8]

Silybum or milk thistle was the most commonly used herbal treatment of liver diseases. Silymarin is the main active constituent. It has been reported that silymarin protects liver cells from a wide variety of toxins, mainly acetaminophen, ethanol, $\mathrm{CCl}_{4}$, and D-galactosamine [9]. Silymarin produced its hepatoprotective effects through several mechanisms including antioxidation [10], inhibition of lipid peroxidation [11], enhanced liver detoxification via inhibition of Phase I detoxification and enhanced glucuronidation [12], and protection of glutathione (GSH) depletion [13].

Silymarin elicited a significant hepatoprotective activity by lowering the levels of serum marker enzymes and lipid peroxidation and elevated the levels of GSH, superoxide dismutase, catalase, albumin (Alb) and total protein (TP) in a dose dependant manner, which was confirmed by the decrease in the total weight of the liver and histopathological examination [14]. Silymarin increases hepatocyte protein synthesis and thus promoting hepatic tissue regeneration [15]. From the animal study, it was proven that silybin reduces the conversion of hepatic stellate cells into myofibroblasts, slowing or even reversing fibrosis [16].

The aim of the proposed work is to develop hepatotoxicity model (chronic) in rats and define chronicity of the disease by measuring various liver parameters and to evaluate hepatoprotective activity of silymarin.

\section{MATERIALS AND METHODS}

\section{Materials}

$\mathrm{CCl}_{4}$ and Arachis oil were purchased from Loba Chemie Pvt Ltd., Mumbai. Silymarin suspension was from Microlabs Ltd., Bengaluru, Karnataka. Serum glutamate pyruvate transaminase (SGPT), serum glutamate oxaloacetate transamina (SGOT), bilirubin, TP, Alb, glucose, cholesterol, and Kits were purchased from Autospan (Span Diagnostic Pvt., Limited Surat)

\section{EXPERIMENTAL PROTOCOL AND PROCEDURE}

\section{Animals}

The experiment was performed after approval from the Institutional Animal Ethics Committee (IAEC). The approved protocol number is RPCP/IAEC/2013-2014/R-32. Healthy Wistar rats of either sex, weighing 200-250 g was taken during the experiment. The animals were housed in the polypropylene cage at $25^{\circ} \mathrm{C} ; 12 \mathrm{hrs}$ dark-light cycle, with free access to standard pellet diet (normal pellet diet) and water ad libitum during the experiment. The animals were acclimatized to surround for 1 week before experiment.

\section{Experimental design}

In rats, chronic liver injury was induced by exposure of hepatotoxicant such as $\mathrm{CCl}_{4}$. The mixture of $\mathrm{CCl}_{4}$ and Arachis oil (1:1) with the dose of $1 \mathrm{ml} / \mathrm{kg}$ was given intraperitoneally (i.p.) [17]

Rats were randomly divided as follows:

- Group Ia and Ib: Received normal saline $1 \mathrm{ml} / \mathrm{kg}$ per day for 7-8 weeks.

- Group IIa: Received $\mathrm{CCl}_{4} 1 \mathrm{ml} / \mathrm{kg} 1^{\text {st }}$ for 10 days daily and then after $1 \mathrm{ml} / \mathrm{kg}$ twice a week up to 7-8 weeks.

- Group IIb: Received $\mathrm{CCl}_{4} 1 \mathrm{ml} / \mathrm{kg} 1^{\text {st }}$ for 10 days alternate and then after $1 \mathrm{ml} / \mathrm{kg}$ twice a week up to 7-8 weeks.

- Group IIIa: Received $\mathrm{CCl}_{4} 1 \mathrm{ml} / \mathrm{kg} 1^{\text {st }}$ for 10 days daily and then after $1 \mathrm{ml} / \mathrm{kg}$ twice a week up to 7-8 weeks.

- Group IIIb: Received $\mathrm{CCl}_{4} 1 \mathrm{ml} / \mathrm{kg} 1^{\text {st }}$ for 10 days alternate and then after $1 \mathrm{ml} / \mathrm{kg}$ twice a week up to 7-8 weeks.

- Group IV: Received $\mathrm{CCl}_{4} 1 \mathrm{ml} / \mathrm{kg}$ (i.p) and $1 \mathrm{ml}$ silymarin suspension (p.o) for 7-8 weeks days.

\section{Blood sample collection}

Blood samples were collected by retro-orbital route in ethylene diamine tetra acetate (EDTA) containing and EDTA-free vials on day 0, 7, 14, $21,28,35$ and 49 during development and treatment of the model. After collection of blood samples, the samples were centrifuged under cooling condition at 4000 RPM for 10-15 minutes to separate plasma and serum. Plasma was used to measure all biochemical parameters such as aspartate aminotransferase (AST), alanine transaminase (ALT), bilirubin, Alb, TP, glucose, cholesterol and malondialdehyde (MDA), whereas serum was used to measure alkaline phosphate (ALP) activity.

\section{Histopathological investigation}

Rats were kept on fasting. Rats of Groups IIa and IIb were sacrificed on day 35, whereas rats of Groups IIIa and IIIb were sacrificed on day 49.

The liver was collected and washed with ice-cold saline. The excised liver was fixed in $10 \%$ formalin solution and taken to the Anand Agricultural University, Department of Histopathology, for histopathological study. The extent of $\mathrm{CCl}_{4}$ induced liver injury was evaluated by assessing the morphological changes in liver sections stained with Haematoxylin and Eosin Stain and Masson trichomes stain to observe liver fibrosis.

\section{Statistical analysis}

All parameters were expressed as a mean value \pm standard deviation. Differences between the mean value of tests and controls were evaluated statistically by Student's t-test. $\mathrm{p}<0.05$ was regarded as statistically significant.

\section{RESULTS AND DISCUSSION}

$\mathrm{CCl}_{4}$ was given daily (for 35 days); there was the rise in ALP, AST, MDA, glucose, cholesterol, and globulin. The similar effect was also seen when it was given alternatively (For 35 days). However, different scenarios were seen in normal controls (Table 1). Same way, when $\mathrm{CCl}_{4}$ was given daily (for 49 days), there was rise in ALP, AST, MDA, glucose, cholesterol, and globulin. The similar effect was also seen when it was given alternatively (for 49 days) (Table 2). When silymarin was given to $\mathrm{CCl}_{4}$ treated group, all liver parameters such as ALP, AST, and ALT are normalized. It also normalizes TP, Alb, MDA, glucose, cholesterol, and globulin similarly as in normal controls (Table 3 ).

\section{Histopathological findings}

The controlled rats show normal liver architecture. They show normal hepatocytes, portal triads vasculature, and bile duct. Whereas rats which were given $\mathrm{CCl}_{4}$ up to 35 days and 49 days show extensive liver damage (Figs. 1 and 2), respectively. Silymarin treated rats show normal liver architecture.

\section{DISCUSSION}

The liver is largest organ and is target for toxicity because of its role in clearing and metabolizing chemicals through the process called detoxification [18]. The most commonly used approach to induce toxinmediated experimental liver fibrosis is the periodic administration of $\mathrm{CCl}_{4}$ in mice or rats [19]. It was used extensively in animal models of acute hepatic failure in the seventies and early eighties. More recently, it has been used in the development of cirrhosis animal models following its gastric and intraperitoneal administration [20]. The most studies rely on the $\mathrm{CCl}_{4}$-model to induce toxic liver fibrosis in mice due to the good comparability, excellent reproducibility, and moderate burden for the animals [19]. Histopathological sectioning of the liver tissues indicated that $\mathrm{CCl}_{4}$ can induce fibrosis, cirrhosis, and hepatocarcinoma [21]. The toxic effect of $\mathrm{CCl}_{4}$ was due to trichloromethyl radical produced during oxidative stress [22]. The liver injury induced by $\mathrm{CCl}_{4}$ increases the number of infiltrated neutrophils, macrophages, Kupffer cells, lymphocytes and natural killer cells which further induced activation of liver resident macrophages and/or chemo attraction of extra hepatic cells (e.g., neutrophils and lymphocytes) [23]. Liver fibrosis, inflammation, and injury were induced by release of activated macrophages [24]. 
Table 1: Change in various serum parameters in rats exposed to $\mathrm{CCl}_{4}$ daily and $\mathrm{CCl}_{4}$ alternate (for 35 days)

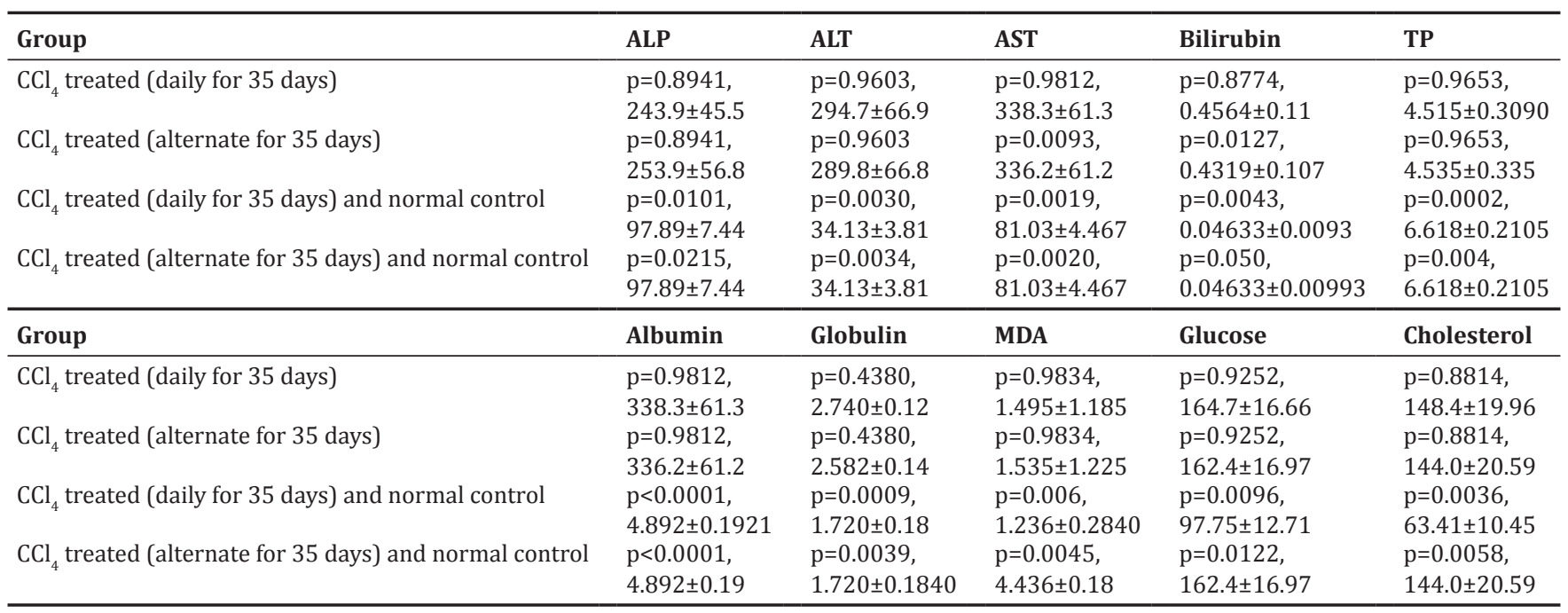

Data were expressed as mean \pm SEM $(n=6)$. Significant difference was indicated by $p<0.5$ compared with normal control group. $p$ value between normal control and $\mathrm{CCl}_{4}$ treated group is $<0.5$, which indicates they are statistically significant. Whereas p value between $\mathrm{CCl}_{4}$ daily and $\mathrm{CCl}_{4}$ alternate group is not $<0.5$, which indicates no significant difference in between this group. ALP: Alkaline phosphate, ALT: Alanine transaminase, AST: Aspartate transaminase, TP: Total protein, MDA: Malondialdehyde, $\mathrm{CCl}_{4}$ : Carbon tetrachloride, SEM: Standard error of the mean

Table 2: Change in various serum parameters in rats exposed to $\mathrm{CCl}_{4}$ daily and $\mathrm{CCl}_{4}$ alternate (for 49 days)

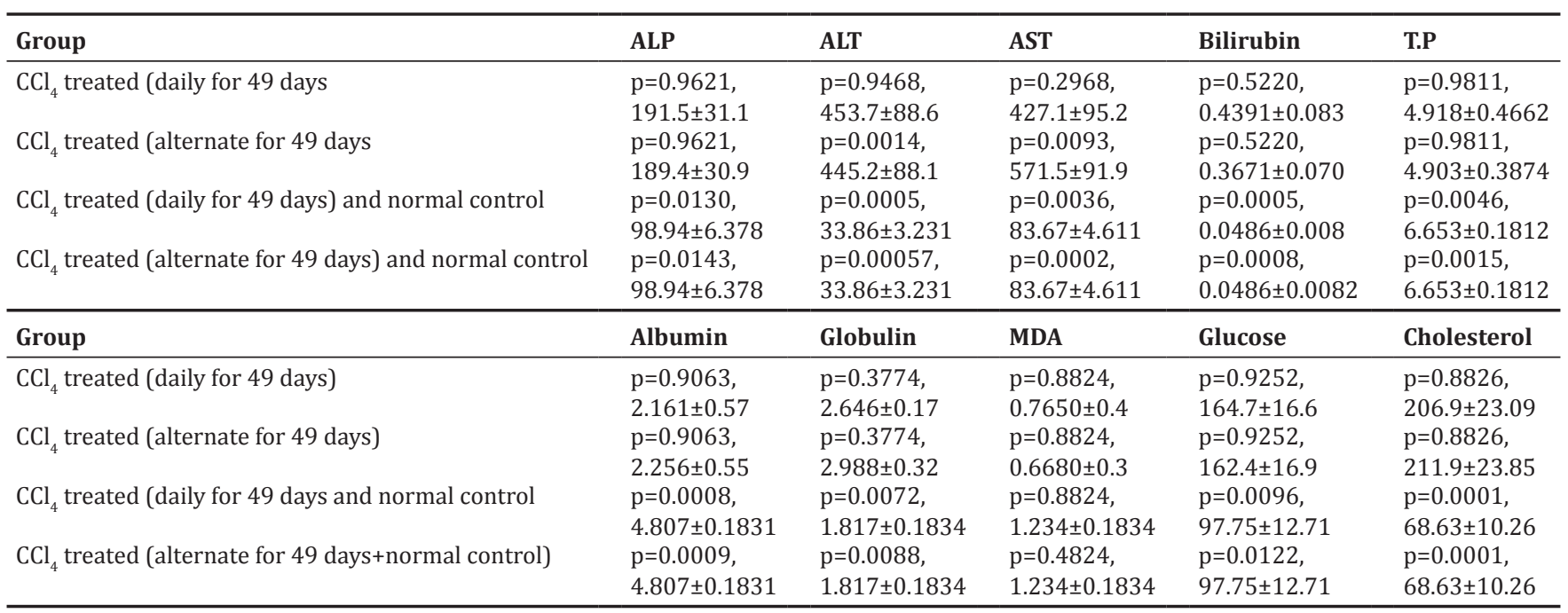

Data were expressed as mean \pm SEM $(n=6)$. Significant difference was indicated by $p<0.5$ compared with normal control group. Here, $p$ value between normal control and $\mathrm{CCl}_{4}$ treated group is $<0.5$, which indicates they are statistically significant. Whereas p value between $\mathrm{CCl}_{4}$ daily and $\mathrm{CCl}_{4}$ alternate group is not $<0.5$, which indicates no significant difference in between this group. ALP: Alkaline phosphate, ALT: Alanine transaminase, AST: Aspartate transaminase, TP: Total protein, MDA: Malondialdehyde, $\mathrm{CCl}_{4}$ : Carbon tetrachloride, SEM: Standard error of the mean

Table 3: Effect of $\mathrm{CCl}_{4}$ and $\mathrm{CCl}_{4}+$ silymarin on various biochemical parameters on wistar rats

\begin{tabular}{llllll}
\hline Group & ALP & ALT & AST & Bilirubin & T.P \\
\hline CCl $_{4}$ treated & $\mathrm{p}=0.9621$, & $\mathrm{p}=0.9468$, & $\mathrm{p}=0.2968$, & $\mathrm{p}=0.5220$, & $\mathrm{p}=0.9811$, \\
& $191.5 \pm 31.1$ & $453.7 \pm 88.6$ & $427.1 \pm 95.2$ & $0.4391 \pm 0.083$ & $4.918 \pm 0.4662$ \\
Silymarin treated & $\mathrm{p}=0.0143$, & $\mathrm{p}=0.00057$, & $\mathrm{p}=0.0002$, & $\mathrm{p}=0.0008$, & $\mathrm{p}=0.0015$, \\
& $98.94 \pm 6.378$ & $33.86 \pm 3.231$ & $83.67 \pm 4.611$ & $0.0486 \pm 0.0082$ & $6.653 \pm 0.1812$ \\
\hline Group & Albumin & Globulin & MDA & Glucose & Cholesterol \\
\hline CCl $_{4}$ treated & $\mathrm{p}=0.9063$, & $\mathrm{p}=0.3774$, & $\mathrm{p}=0.8824$, & $\mathrm{p}=0.9252$, & $\mathrm{p}=0.8826$, \\
& $2.161 \pm 0.57$ & $2.646 \pm 0.17$ & $0.7650 \pm 0.4$ & $164.7 \pm 16.6$ & $206.9 \pm 23.09$ \\
Silymarin treated & $\mathrm{p}=0.9063$, & $\mathrm{p}=0.3774$, & $\mathrm{p}=0.8824$, & $\mathrm{p}=0.9252$, & $\mathrm{p}=0.8826$, \\
& $2.256 \pm 0.55$ & $2.988 \pm 0.32$ & $0.6680 \pm 0.3$ & $162.4 \pm 16.9$ & $211.9 \pm 23.85$ \\
\hline
\end{tabular}

Data were expressed as mean \pm SEM ( $n=6$ ). Significant difference was indicated by $p<0.5$ compared with normal control group. Here $p$ value between normal control and $\mathrm{CCl}_{4}$ treated group, $\mathrm{CCl}_{4}$ treated group and silymarin treated group is $<0.5$, so they were statistically significant. ALP: Alkaline phosphate, ALT: Alanine transaminase, AST: Aspartate transaminase, TP: Total protein, MDA: Malondialdehyde, $\mathrm{CCl}_{4}$ : Carbon tetrachloride, SEM: Standard error of the mean 
For acute liver injury rats were administered a single dose of $\mathrm{CCl}_{4}$, $2 \mathrm{ml} / \mathrm{kg}$ of body weight which leads to liver fibrosis. The chronic dose of $\mathrm{CCl}_{4}$ was $2 \mathrm{ml} / \mathrm{kg}$ of body weight twice per week which result in liver fibrosis [25]. In this study, the development of chronic model rats was administered $1.0 \mathrm{ml} / \mathrm{kg}$ of body weight of $\mathrm{CCl}_{4}$ i.p. for 10 days daily and then after $1 \mathrm{ml} / \mathrm{kg}$ twice a week up to 7-8 weeks.

\section{Serum aminotransferase enzymes}

Upon cellular membrane damage and leakage serum activities were increased [26]. In all types of liver injury, serum aminotransferase activities were increased. Serum estimation of SGPT was specific for the liver tissue so in liver cell injury serum SGPT was of greater value, whereas SGOT level may increase in acute necrosis or ischemia of other organs such as the myocardium, besides the liver cell injury.

In this study, serum AST, ALT, ALP, and bilirubin activities were greatly increased $(\mathrm{p}<0.05)$ in rats exposed to $\mathrm{CCl}_{4}$ as compare to normal control. The increased serum levels of hepatic markers have been attributed to the liver injury because these enzymes are placed in the cytoplasmic area of the cell and are released into circulation in case of cellular damage [27].

Zimmerman et al. stated that serum level of ALP, AST, ALT, and bilirubin was increased by mitochondrial damage in liver cells this damage was induced by $\mathrm{CCl}_{4}$ [28]. The activities of liver enzymes were significantly elevated after $\mathrm{CCl}_{4}$ treatment this was reported by many authors $[29,30]$

Binita et al. reported that chronic liver fibrosis was induced in Wistar rats by oral administration of $\mathrm{CCl}_{4}$ for 7 weeks [31], whereas in the present study liver fibrosis was induced within 5 weeks. The proposed animal model in this study fulfilled the criteria described by Terblanche and Hickman [32].

It has been reported that silymarin stabilizes the membrane of hepatocytes, preventing toxins from entering the cell through enterohepatic recirculation, regenerates liver by stimulating nucleolar polymerase A and increasing ribosomal protein synthesis [33]. Silymarin comprises a strong antioxidant and anti-inflammatory potential [33]. Silymarin inhibits hepatic lipid peroxidation, thus it protects against membrane damage. Toxicity effect of $\mathrm{CCl}_{4}$ was controlled by restoration of serum bilirubin, proteins and enzymes [34].

In the present study, silymarin improves liver function. It decreases liver SGPT, SGOT, ALP, Bilirubin, MDA, and globulin level. Silymarin also controls TP and Alb level. Silymarin helps in regenerating liver tissue, controls inflammation, enhances glucuronidation, and protects against GSH depletion. The non-traditional use of silymarin protects other organs along with the liver. Silymarin also prevents the absorption of toxins into hepatocytes by occupying to the binding site and also inhibits the transport of protein into the membranes [35].

\section{Histopathological investigations}

The histopathological evaluation of $\mathrm{CCl}_{4}$-induced toxicity in all groups at the different time intervals was examined. The normal control group (Fig. 3) shows no abnormalities, whereas in $\mathrm{CCl}_{4}$ treated group (both day 35 and day 49) shows liver abnormalities. On day 35, liver fibrosis (Fig. 1) was seen and on day 49, liver cirrhosis was seen (Fig. 2). Silymarin treated animals show normal liver architecture (Fig. 4).

\section{CONCLUSION}

From the results, it was concluded that $\mathrm{CCl}_{4}$ has potential to cause chronic liver injury (fibrosis and cirrhosis). The proposed animal model of chronic liver injury might be suitable for screening of drugs used to treat liver injury and associated disorders. Here, silymarin as a standard drug shows hepatoprotective effect in the developed model.

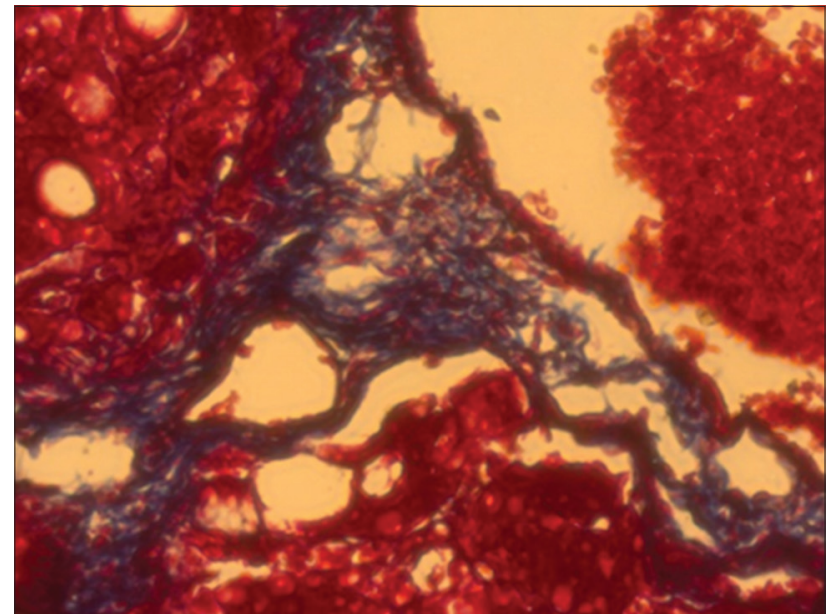

Fig. 1: Masson's trichome stain reveled proliferation of fibrous connective tissue in hepatic (on day 35) (carbon tetrachloride $1 \mathrm{ml} / \mathrm{kg}$ )

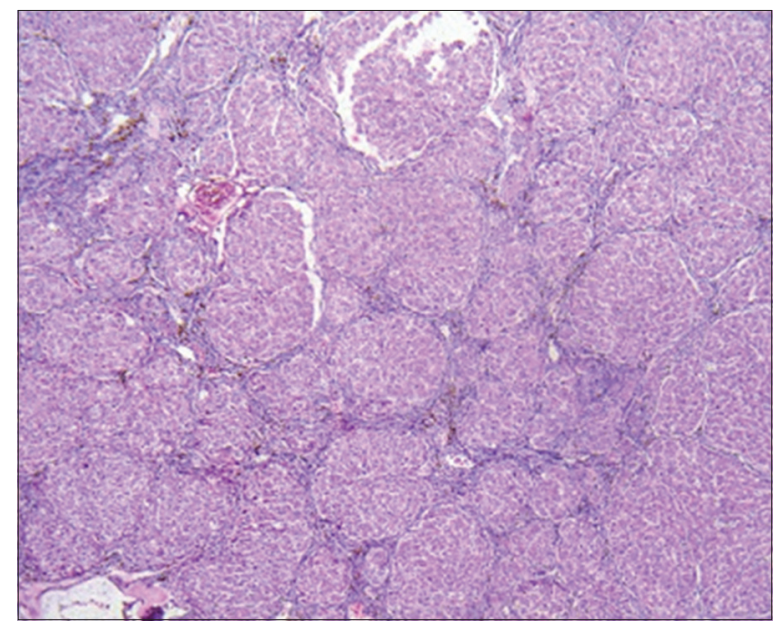

Fig. 2: Proliferation fibrous were evident in hepatic lobule resulting into pseudolobulation (on day 49) (carbon tetrachloride $1 \mathrm{ml} / \mathrm{kg}$ )

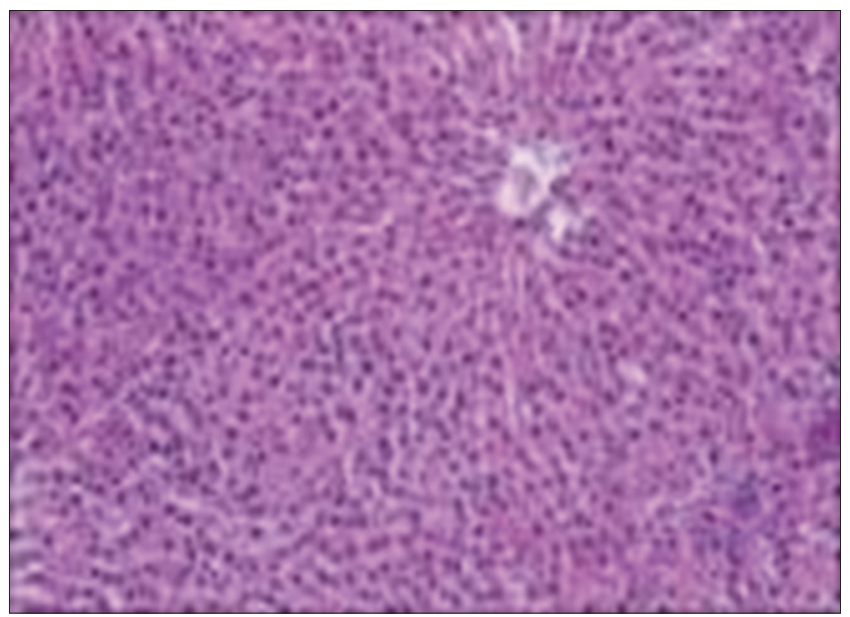

Fig. 3: Normal histology of liver

\section{ACKNOWLEDGMENTS}

The author is thankful to Dr. B.G.Patel for his scientific advice. The author wants to thank Ms. Gopi Shah for her writing assistance. 


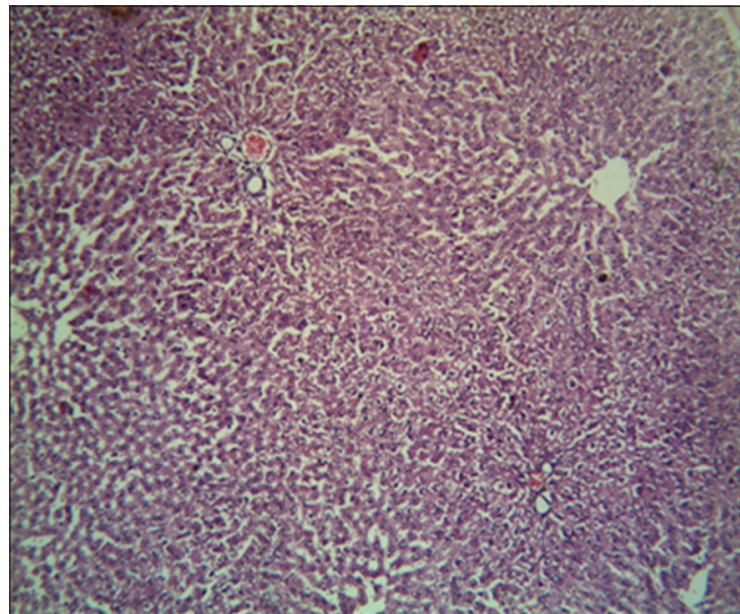

Fig. 4: Did not reveal any specific changes (carbon tetrachloride [CCl4]+silymarin) (CCl4 $1 \mathrm{ml} / \mathrm{kg}+$ silymarin suspension $3 \mathrm{ml} /$ animal)

\section{REFERENCES}

1. Banrida W, Juliane IB, Heather BC, Bellis JH, Cameron FK, Craig JM, et al. Toxicant-associated steatohepatitis. Toxicol Pathol 2013;41:343-60.

2. Cave M, Falkner KC, McClain CJ. Occupational and environmental liver disease. In: Zakim and Boyer's Hepatology: A Textbook of Liver Disease. Philadelphia, PA: Elsevier Saunders; 2011. p. 476-92.

3. Friedman SL. Liver fibrosis. J Hepatol 2003;38(1):S38-53.

4. Bigoniya P, Singh CS, Shukla A. A comprehensive review of different liver toxicants used in experimental pharmacology. Int J Pharm Sci Drug Res 2009;1(3):124-35.

5. Renner $\mathrm{H}$. The limited relevance of models used for testing human hepatic diseases and their prevention. In: Keppler E, Popper H, Bianchi L, Reutter W, editors. Mechanisms of Hepatocyte Injury and Death. Lancaster: MTP Press Ltd.; 1985. p. 311-20.

6. Cotran RS, Kumar V, Robbins SL. Genetic disorders. In: Cotran RS, Kumar V, Robbins SL, editors. Pathologic Basis of Disease. Vol. 5. Philadelphia, PA: WB Saunders Co.; 1994. p. 143.

7. Kaplowitz N, Aw TY, Simon FR, Stolz A. Drug-induced hepatotoxicity. Ann Intern Med 1986;104(6):826-39.

8. Kanchana N, Sadiq AM. Hepatoprotective effect of Plumbago zeylanica on paracetamol induced liver toxicity in rats. Int J Pharm Pharm Sci 2011;3:151-4.

9. Muriel P, Garciapiña T, Perez-Alvarez V, Mourelle M. Silymarin protects against paracetamol-induced lipid peroxidation and liver damage. J Appl Toxicol 1992;12(6):439-42.

10. Wagner H. Plant constituents with antihepatotoxic activity. In: Beal JL, Reinhard E, editors. Natural Products as Medicinal Agents. Stuttgart: Hippokrates-Verlag; 1981.

11. Bosisio E, Benelli C, Pirola O. Effect of the flavanolignans of Silybum marianum L. on lipid peroxidation in rat liver microsomes and freshly isolated hepatocytes. Pharmacol Res 1992;25(2):147-54.

12. Baer-Dubowska W, Szaefer H, Krajka-Kuzniak V. Inhibition of murine hepatic cytochrome P450 activities by natural and synthetic phenolic compounds. Xenobiotica 1998;28(8):735-43.

13. Campos R, Garrido A, Guerra R, Valenzuela A. Silybin dihemisuccinate protects against glutathione depletion and lipid peroxidation induced by acetaminophen on rat liver. Planta Med 1989;55(5):417-9.

14. Sandhu NS, Chopra D, Kaur S. Amelioration of paracetamol induced hepatotoxicity by a protein isolated from the leaves of the herb Cajanus Acutifolius Linn. Int J Pharm Pharm Sci 2010;2(3):75-80.

15. Sonnenbichler J, Zetl I. Biochemical effects of the flavanolignane silibinin on RNA, protein and DNA synthesis in rat livers. In: Cody V, Middleton E, Harbourne JB, editors. Plant Flavonoids in Biology and Medicine: Biochemical, Pharmacological, and Structure-Activity Relationships. New York, NY: Alan R. Liss; 1986. p. 319-31.

16. Fuchs EC, Weyhenmeyer R, Weiner OH. Effects of silibinim and of a synthetic analogue on isolated rat hepatic stellate cells and myofibroblasts. Arzneimittelforschung 1997;26:643-9.

17. Khan AA, Alzohairy M. Hepatoprotective effects of camel milk

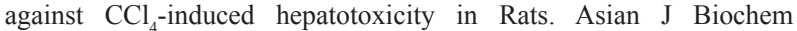
2011;6(2):171-80.

18. Larrey D. Drug-induced liver diseases. J Hepatol 2000;32 1 Suppl:77-88.

19. Liedtke C, Luedde T, Sauerbruch T, Scholten D, Streetz K, Tacke F, et al. Experimental liver fibrosis research: Update on animal models, legal issues and translational aspects. Fibrogenesis Tissue Repair 2013;6:19

20. Nakano A, Kanda T, Abe H. Bone changes and mineral metabolism disorders in rats with experimental liver cirrhosis. J Gastroenterol Hepatol 1996;11:1143-54.

21. Karakus E, Karadeniz A, Simsek N, Can I, Kara A, Yildirim S, et al. Protective effect of Panax ginseng against serum biochemical changes and apoptosis in liver of rats treated with carbon tetrachloride $\left(\mathrm{CCl}_{4}\right)$. J Hazard Mater 2011;195:208-13.

22. Stoyanovsky DA, Cederbaum AI. Metabolism of carbon tetrachloride to trichloromethyl radical: An ESR and HPLC-EC study. Chem Res Toxicol 1999;12(8):730-6.

23. Ramadori G, Saile B. Portal tract fibrogenesis in the liver. Lab Invest 2004;84:153-9.

24. Saile B, Ramadori G. Inflammation, damage repair and liver fibrosis - Role of cytokines and different cell types. Z Gastroenterol 2007:45(1):77-86.

25. Yu C, Wang F, Jin $\mathrm{C}, \mathrm{Wu} \mathrm{X}$, Chan WK, McKeehan WL. Increased carbon tetrachloride-induced liver injury and fibrosis in FGFR4deficient mice. Am J Pathol 2002;161(6):2003-10.

26. Kaplan MM. Laboratory tests. In: Schiff L, Schiff ER, editors. Diseases of the Liver. Vol. 7. Philadelphia, PA: JB Lippincott; 1993. p. 108-44.

27. Brent JA, Rumack BH. Role of free radicals in toxic hepatic injury. II. Are free radicals the cause of toxin-induced liver injury? J Toxicol Clin Toxicol 1993;31(1):173-96.

28. Zimmerman HJ, Kodera Y, West M. Effects of carbon tetrachloride poisoning on the plasma levels of cytoplasmic and mitochondrial enzymes in animals with nutritional fatty metamorphosis. J Lab Clin Med 1965;66:324-33.

29. Mehmetçik G, Ozdemirler G, Koçak-Toker N, Cevikbas U, Uysal M. Role of carnosine in preventing thioacetamide-induced liver injury in the rat. Peptides 2008;29(3):425-9.

30. Arıc1 OF, Cetin N. Protective role of ghrelin against carbon tetrachloride $\left(\mathrm{CCl}_{4}\right.$ induced coagulation disturbances in rats. Regul Pept 2011;166:139-42.

31. Binita S, Mehul C, Vandit T. Anti-fibrotic effect of heparin, silymarin and its combination on liver fibrosis model in rats. J Pharm Res Opin 2011;6:180-6.

32. Terblanche J, Hickman R. Animal models of fulminant hepatic failure. Dig Dis Sci 1991;36:770-4.

33. Mayer KE, Myers RP, Lee SS. Silymarin treatment of viral hepatitis: A systematic review. J Viral Hepat 2005;12:559-67.

34. Goudar MA, Jaydevappa H, Mahadevan KM, Shastry RA, Habbu PV, Sayeswar HA, et al. Isolation and characterization of secondary metabolite from habenaeria intermedia D. DON for screening hepatoprotective potential against carbon tetrachloride induced toxicity in albino rat liver. Int J Curr Pharm Res 2015;7(1):57-61.

35. Pradhan SC, Girish C. Hepatoprotective herbal drug, silymarin from experimental pharmacology to clinical medicine. Indian J Med Res 2006;124(5):491-504. 